\title{
THE INFLUENCE FACTORS OF GOVERNMENT SUPPORT, POLITICAL CONDITIONS, AND BUSINESS COMPETITION ON THE PERFORMANCE OF CONSTRUCTION SERVICES COMPANY PT WIJAYA KARYA (Persero) Tbk
}

\author{
Dwi Afriyanto \\ PT Wijaya Karya \\ Email: dafriyanto@gmail.com
}

\begin{abstract}
The objective research is to obtain information on the effect of government support, political conditions and business competition in order to improve the performance of construction services company. Survey research methodology used survey. Data collection done toward 133 respondents. Respondent were chosen by simple random sampling technique. The data were collected with questionnaire and analysis with multiple regression. The results of the analysis concluded that the government support, political conditions and business competition have influence by direct or indirect on the performance of construction services company. The hypothesis is proven by indicators of significance of the influence between variable that more than $(<) \alpha=0,05$ and also the result of T-test that $T$ count more than (>) $T$ table., the most dominant variable is political conditions in influencing the performance of construction services company with significance value of 0.000 .
\end{abstract}

Keywords : Government support, Political condition, Business competition, and Performance of the company. 


\section{Latar Belakang}

Saat ini industri Jasa Konstruksi mendapat sorotan banyak pihak di berbagai negara, mengingatsumbangsihnya yang signifikan terhadap banyaksektor terutama ekonomi. Hingga ditargetkan pertumbuhan ekonomi Indonesia di tahun 2014 minimal 7 persen, suatu pencapaian yang harusdidukung oleh Infrastruktur yang baik secara fisik maupun dari sisi sumber daya manusianya.Di samping kebutuhan memperkuat struktur sektor konstruksi, satu hal yang patut menjadiperhatian adalah agar setiap sektor saling mendukung untuk mendorong pertumbuhan ekonomiserta pembangunan pada umumnya.

Sektor konstruksi sebagai salah satu penyumbang terbesar pada Gross Domestic Product (GDP) perekonomian Indonesia, sektor konstruksi tidak bisa dipungkiri memiliki peran strategis dalam pembangunan. Peran strategis itu antara lain pada penyerapan tenaga kerja, jangkauan rantai pemasok yang luas, pendorong sector-sektor pendukungnya, bahkan mobilisator pertumbuhan produk nasional baik barang maupun jasa.Berdasarkan atas data Biro Statistik bahwa sektor konstruksi merupakan penyumbang untuk laju pertumbuhan sebesar $7.5 \%$ (BPS, 2012).

Sektor konstruksi memainkan peran yang sangat strategis dalam pembangunan ekonomi nasional. Memperhatikan pentingnya peran sektork onstruksi tersebut, maka perlu kiranya dilakukan pembinaan dan pengembangansektor konstruksi secara serius, terencana, dan konsisten. Data dari Pusat Pembinaan Sumber Daya Investasi menunjukan adanya indikasi terjadi distrosi pasar konstruksi domestic yang disebabkan oleh disparitas permintaan penyediaan jasa konstruksi. Hal ini diperkuat dengan pernyataan beberapa kalangan yang mengindikasikan bahwa 60\% dari pasar konstruksi domestrik dikuasi oleh badan usaha kualifikasi besar (termasuk badan usaha asing) yang jumlahnya hanya 1\% (1.500 badan usaha) dari seluruh badan usaha penyedia jasa konstruksi. Komisi Pengawas Persaingan Usaha, menjelaskan berdasarkan kategori status pelaku usaha nilai transaksi di tahun 2011 untuk merger perusahaan asing lebih dominan dibandingkan merger perusahaan domestik. Yaitu 
sebesar 56\%dari total keseluruhan transaksi, sedangkan untuk merger perusahaan domestic hanya 7\% (KPPU, 2012).

\section{Kajian Teoritik}

\section{Kinerja Perusahaan}

Kinerja perusahaan merupakan sesuatu yang dihasilkan oleh suatu perusahaan dalam periode tertentu dengan mengacu pada standar yang ditetapkan. Kinerja perusahaan hendaknya merupakan hasil yang dapat diukur dan menggambarkan kondisi empirik suatu perusahaan dari berbagai ukuran yang disepakati. Untuk mengetahui kinerja yang dicapai maka dilakukan penilaian kinerja.

Sistem penilaian kinerja yang efektif sebaiknya mengandung indikator kinerja, yaitu: (1) memperhatikan setiap aktivitas organisasi dan menekankan pada perspektif pelanggan, (2) menilai setiap aktivitas dengan menggunakan alat ukur kinerja yang mengesahkan pelanggan, (3) memperhatikan semua aspek aktivitas kinerja secara komprehensif yang mempengaruhi pelanggan, dan (4) menyediakan informasi berupa umpan balik untuk membantu anggota organisasi mengenali permasalahan dan peluang untuk melakukan perbaikan. Lebih jauh Atkinson, Banker, Kaplan dan Young (1995) mengatakan bahwa the role of performance assessment in helping organization members to manage the value chain.

Penilaian kinerja perusahaan dapat diukur dengan ukuran keuangan dan non keuangan. Ukuran keuangan untuk mengetahui hasil tindakan yang telah dilakukan dimasa lalu dan ukuran keuangan tersebut dilengkapi dengan ukuran non keuangan tentang kepuasan customer, produktivitas dan cost effectiveness proses bisnis/intern serta produktivitas dan komitmen personel yang akan menentukan kinerja keuangan masa yang akan datang. Ukuran keuangan menunjukkan akibat dari berbagai tindakan yang terjadi diluar non keuangan.

Hal diatas menjelaskan bahwa aktivitas penilaian kinerja terdapat dua jenis pengukuran yaitu; keuangan dan non keuangan. Pengukuran ini dirancang untuk menaksir bagaimana kinerja aktivitas dan hasil akhir yang dicapai. Ada 
juga penilaian kinerja yang dirancang untuk menyingkap jika terjadi kemandekan perbaikan yang akan dilakukan. Penilaian kinerja aktivitas pusat dibagi kedalam tiga dimensi utama, yaitu: (1) effisiensi, (2) kualitas, (3) waktu (Hansen and Mowen, 2007). Hal senada juga dijelaskan oleh Kaplan dan Norton, (1996); Lingle dan Schiemann, (1996) pengukuran kinerja non keuangan didesain untuk menilai seberapa baik aktivitas yang berhasil dicapai dan dipusatkan pada tiga dimensi utama yaitu efisiensi, kualitas dan waktu. Dimensi pengukuran kinerja perusahaan menurut Adeoye et al (2012) yang akan peneliti lakukan pada penelitian ini adalah sebagai berikut efektifitas, efisiensi, peningkatan penjualan dan pencapaian tujuan perusahaan.

\section{Dukungan Pemerintah}

Pasar usaha jasa konstruksi di Indonesia sangat berpotensi, dimana kegiatan investasi yang dilakukan oleh pemerintah dan sektor swasta setiap tahunnya meningkat. Hal ini, berkaitan juga dengan cakupan wilayah dan jumlah masyarakat (publik) yang mesti mendapatkan pelayanan. Perlunya dukungan pemerintah, maupun fasilitasi keuangan yang dapat berupa kemudahan fiskal, dukungan modal maupun jaminan bank, serta legalitas mengenai pengaturan yang jelas mengenai pengaturan yang jelas mengenai liberalisasi jasa dan investasi (Pusat Komunikasi Publik, 2006).

Dukungan pemerintah adalah kontribusi fiscal atau non fiscal yang diberikan oleh Menteri / Kepala Lembaga / Kepala Daerah dan / atau Menteri Keuangan sesuai wewenang masing-masing berdasarkan peraturan perundangundangan dalam rangka meningkatkan kelayakan finansial proyek kerjasama (PermenBapenas, 2012). Menurut Mole (2002) mencatat bahwa dukungan pemerintah sebagai bantuan dari pemerintah dan lembaga-lembaga untuk usaha kecil dalam bentuk saran pembiayaan, pelatihan, dan pendampingan dalam rangka meningkatkan dan mengembangkan mereka. Sedangkan kebijakan pemerintah mempunyai pengertian baku yaitu suatu keputusan yang dibuat secara sistematik oleh pemerintah dengan maksud dan tujuan tertentu yang menyangkut kepentingan umum (Anonimous, 1992). Dukungan pemerintah adalah dukungan 
secara politis, maupun fasilitasi keuangan yang dapat berupa kemudahan fiskal, dukungan modal maupun jaminan bank, serta legalitas mengenai pengaturan yang jelas mengenai pengaturan yang jelas mengenai liberalisasi jasa dan investasi (Pusat Komunikasi Publik, 2006).

Rintuh (1995) menjelaskan intervensi pemerintah dalam perekonomian dilakukan untuk meningkatkan pengeluaran pemerintah. Peranan pemerintah dalam meningkatkan kinerja perusahaan hendaknya mendapat respon dari pihak perusahaan. Keadaan ini dapat menggairahkan mereka untuk melakukan peningkatan usahanya untuk memasuki pasar internasional. Hal ini terlihat semenjak Indonesia merubah kebijakan perdagangan luar negerinya dari substitusi impor ke tahap promosi ekspor dengan menerbitkan sejumlah paket deregulasi. Gnyawali dan Fogel (1994) dalam Alkali dan Hasan percaya bahwa kondisi sosial ekonomi dan kebijakan pemerintah memainkan peran penting dalam kecenderungan untuk enterprise. Mereka berpendapat bahwa faktor-faktor seperti dukungan dari lembaga pemerintah menciptakan budaya perusahaan yang memungkinkan perusahaan untuk mencari keuntungan.

Dukungan pemerintah dan hubungannya dengan kinerja organisasi adalah sangat penting untuk bisnis dan ini mendorong sebagian besar negara diseluruh dunia untuk beradaptasi dengan berbagai jenis program. Di Negara maju, pemerintah menawarkan berbagai layanan pendukung dengan keyakinan yang kuat dalam peran penting yang dimainkan oleh usaha kecil dalam pengembangan ekonomi Negara tersebut. Di Negara-negara berkembang, permintaan untuk adanya dukungan pemerintah meningkat karena adanya hambatan-hambatan dalam usaha bisnisnya (Lazim et al, 2013).

Menurut penelitian yang dilakukan oleh Lazim dan Azlinna Binti Azizan (2013), dimensi dukungan pemerintah yaitu terdiri dari dukungan keuangan dan dukungan keuangan. Menurut Basri (2008) dan CIBD (2010) dalam Taherkhani et al, dimensi dari dukungan pemerintah terdiri dari 3 dimensi yaitu kebijakan dan insentif pemerintah, sikap dan dukungan pembiayaan penelitian. 


\section{Kondisi Politik}

Ditinjau dari segi perspektif ekonomi industri, faktor politik dapat menjadi penghalang dalam melakukan ekspor kesuatu negara. Begitu juga dengan undangundang yang berlaku pada suatu negara dapat menjadi penghalang perdagangan internasional. Misalnya kebijakan tarif yang diterapkan oleh suatu negara akan meningkatkan harga jual suatu produk, sehingga sulit bersaing dengan produk lainnya (Baldauf et al, 2000).

Gejolak kehidupan politik, secara langsung maupun tidak langsung akan mempengaruhi kondisi ekonomi sebuah Negara. Jika pengusaha ingin melakukan operasional perusahaannya secara signifikan akan dipengaruhi oleh kondisi politik dinegara dimana ia beroperasi (whitelock dan Jobber, 2004).

Dalam jurnal penelitian Adeoye dan Elegunde (2012) disimpulkan bahwa pengaruh kondisi politik suatu negara mempengaruhi kinerja perusahaan secara signifikan pada industri makanan dan minuman di Nigeria dengan dimensi pengujian yang terdiri dari kondisi politik dinegara tersebut, kerangka hukum dan hubungan dengan pemegang kekuasaan.

Dalam jurnal penelitian yang dilakukan oleh Taherkhani (2012) disampaikan bahwa dimensi tersebut adalah transportasi (Chung, 2006 dan Hong, 2006), standarisasi dan Undang-undang (CIBD, 2010), pusat riset dan pengembangan (Chung, 2006 dan CIBD 2010).

\section{Persaingan Usaha}

Suatu perusahaan yang menginginkan survive dan keluar sebagai pemenang dalam bisnis yang kompetitif (comparative advantage and competitive advantage) harus menciptakan pola kebijakan perusahaan yang komprehensif yang tidak hanya melihat organisasi perusahaan saat ini tetapi juga berorientasi untuk mencapai keunggulan bersaing di masa yang akan datang. Persaingan yang semakin ketat dimasa mendatang memerlukan kreasi strategi baru berupa pola strategi yang spesifik dan memadai (Kusmayadi, 2008). Pola tersebut harus dapat menampung perubahan-perubahan yang terjadi dilingkungan bisnis dimasa mendatang (Barlett, Ghoshall: 1999), karena perusahaan yang berhasil 
menyelaraskan atau yang menunjukan tingkat adaptif dan fleksibilitas tinggi dengan lingkungan memperlihatkan kinerjanya yang lebih baik dibandingkan perusahaan yang kurang berhasil menyelaraskan strategi atau menunjukkan tingkat adaptif dan fleksibilitas yang rendah (Beal: 2000, Elenkov: 1997).

Dengan demikian manajemen yang efektif adalah yang melihat bisnis secara keseluruhan, yang dapat menyeimbangkan kebutuhan perusahaan sekarang dengan kebutuhan yang akan datang, serta dapat membuat keputusan logis secara tepat waktu (Hunger, Wheelen: 2007). Kemampuan dan pemahaman tersebut akan mendorong lahirnya strategi yang mampu menjadi solusi terbaik dalam memanfaatkan peluang (opportunites) sekecil apapun untuk menutupi kelemahan (Weaknessess), disamping memanfaatkan kekuatan (Strengths) yang ada untuk menghadapi atau menghindari ancaman (Threats) agar perusahaan dapat mempertahankan kesinambungan (survival), pertumbuhan (growth) serta meningkatkan kemampulabaan (profitability) (David : 2003).

\section{Hipotesis Penelitian}

Berdasarkan uraian kerangka teoritik diatas, maka hipotesis dalam penelitian ini ialah:

a. Ada Pengaruh Dukungan Pemerintah terhadap Kinerja Perusahaan.

b. Ada Pengaruh Kondisi Politik erhadap Kinerja Perusahaan.

C. Ada Pengaruh Persaingan Usaha terhadap Kinerja Perusahaan.

d. Ada Pengaruh Dukungan Pemerintah, Kondisi Politik dan Persaingan Usaha secara simultan terhadap kinerja perusahaan.

\section{Metode Penelitian}

Metode penelitian dalam penelitian ini adalah deskriptif dan kausal. Menurut Malhotra (2005), penelitian deskriptif dan kausal sering kali disebut penelitian konklusif (conclusive), sebab keduanya berusaha memberikan kesimpulan akhir (conclusion). Penelitian deskriptif adalah suatu jenis riset konklusif yang mempunyai tujuan utama menguraikan sesuatu. Pendekatan yang dipakai itu dipakai sebagai alat melihat dan menggali yang dapat dilakukan sepanjang 
melakukan penelitian. Dalam penelitian ini akan mendeskripsikan bahwa dukungan pemerintah, kondisi politik dan persaingan usaha berpengaruh besar terhadap kinerja perusahaan jasa konstruksi di Indonesia.

\section{Kerangka Teoretik}

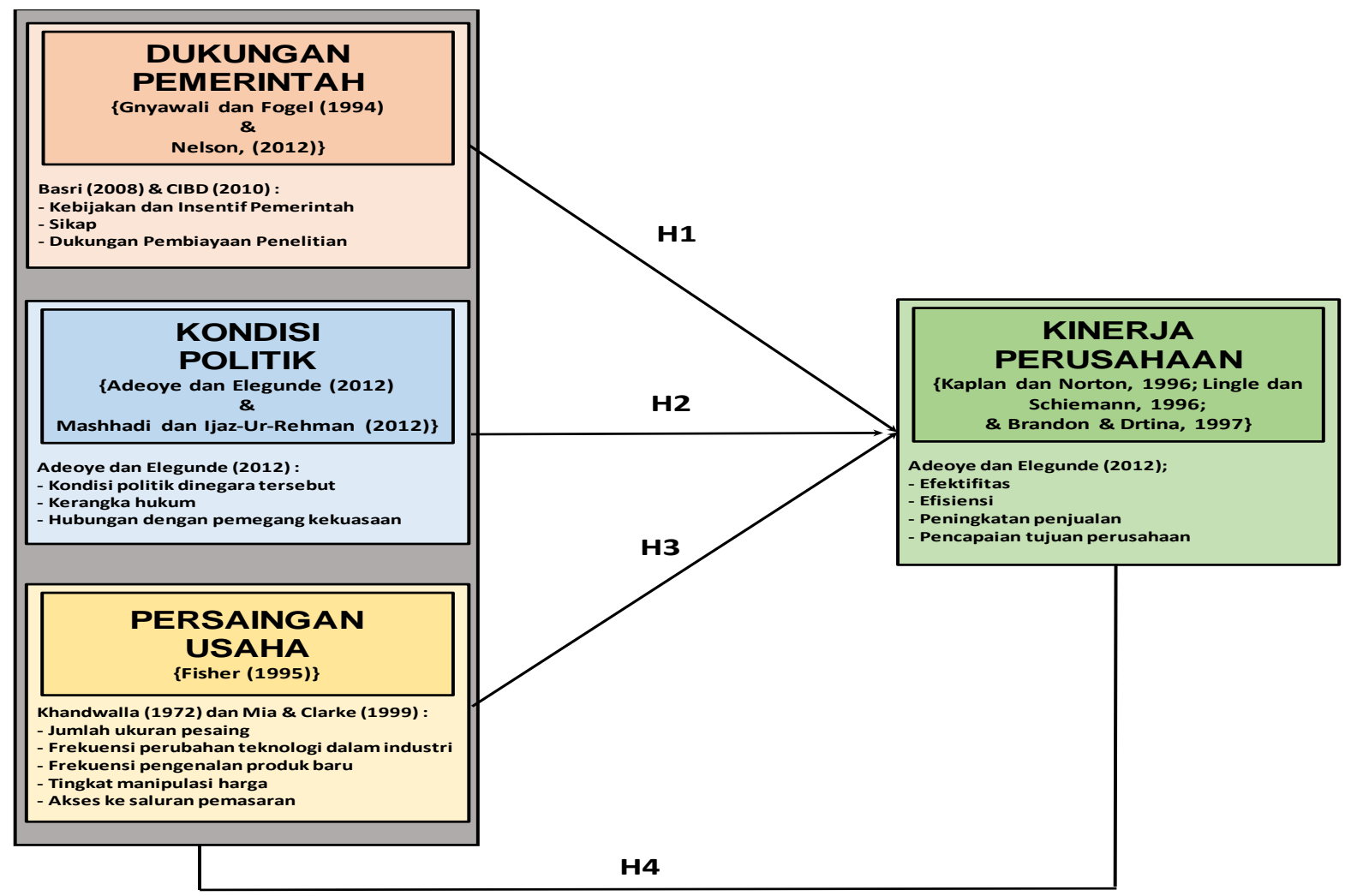

\section{Populasi Penelitian}

Populasi dalam penelitian ini adalah Pegawai PT. Wijaya Karya (Persero) Tbk Departemen Industrial Plant sebanyak 200 orang, tersaji pada Tabel 3.1.

\section{Sampel Penelitian}

Metode pengambilan sampel dalam penelitian ini adalah probability sampling yaitu teknik pengambilan sampel yang memberikan peluang yang sama bagi setiap unsur (anggota) populasi untuk dipilih menjadi anggota sampel dengan teknik pengambilan sampel yang digunakan adalah proportionate stratified random sampling, yaitu bila populasi penelitian mempunyai anggota/unsur yang tidak 
homogeny dan berstrata secara proporsional. Untuk menentukan besarnya sampel maka digunakan rumus Slovin yaitu sebagai berikut:

$\mathrm{n}=\frac{\mathrm{N}}{\left(1+\mathrm{Ne}^{2}\right)}$

Keterangan :

$\mathrm{n}=$ Ukuran sampel

$\mathrm{N}=$ Ukuran populasi

$\mathrm{e}=5 \%$ tingkat kelonggaran ketidaktelitian karena kesalahan pengambilan sampel yang dapat ditoleransi penghitungan untuk sampel dari populasi

$\mathrm{n}=200 /\left(1+200(0.05)^{2}\right)$

$=133.33$

$=133$ (pembulatan ke bawah)

Jadi, sampel untuk pegawai PT. Wijaya Karya (Persero) Tbk Departemen Industrial Plant yang akan digunakan adalah sebanyak 133 orang

Tabel Populasi Penelitian

\begin{tabular}{|l|l|c|}
\hline No. & \multicolumn{1}{|c|}{ Unit Kerja } & Total \\
\hline 1 & Departemen & 150 \\
\hline 2 & Proyek-proyek & 50 \\
\hline & Total & 200 \\
\hline
\end{tabular}

\section{Identifikasi Variabel}

Variabel Operasional Dukungan Pemerintah 


\begin{tabular}{|c|c|c|}
\hline Variabel & Dimensi & \begin{tabular}{|l} 
Sub Indikator \\
\end{tabular} \\
\hline \multirow{4}{*}{$\begin{array}{l}\text { Dukungan } \\
\text { Pemerintah }\end{array}$} & $\begin{array}{l}\text { Kebijakan dan } \\
\text { insentif } \\
\text { pemerintah }\end{array}$ & $\begin{array}{l}\text { a. Menjaga iklim usaha jasa konstruksi yang kondusif } \\
\text { b. Legalitas pengaturan yang jelas mengenai } \\
\text { liberalisasi jasa } \\
\text { c. Legalitas pengaturan yang jelas mengenai } \\
\text { liberalisasi investasi }\end{array}$ \\
\hline & $\begin{array}{c}\text { Insentif } \\
\text { pemerintah }\end{array}$ & $\begin{array}{l}\text { d. Fasilitasi keuangan berupa kemudahan fiskal } \\
\text { e. Fasilitasi keuangan berupa dukungan modal } \\
\text { f. Fasilitasi keuangan berupa jaminan Bank }\end{array}$ \\
\hline & Sikap & $\begin{array}{l}\text { g. Dukungan pemerintah dalam Penyertaan } \\
\text { Modal Kerja (PMN) } \\
\text { h. Dukungan pemerintah dalam pengawasan } \\
\text { operasional perusahaan BUMN Konstruksi } \\
\text { i Dukungan secara politis }\end{array}$ \\
\hline & $\begin{array}{l}\text { Dukungan } \\
\text { pembiayaan } \\
\text { penelitian }\end{array}$ & $\begin{array}{l}\text { j. Kementrian BUMN memberikan fasilitas } \\
\text { untuk penelitian } \\
\text { k. Bekerjasama dengan Kementrian PU-Pera } \\
\text { dalam penelitian } \\
\text { I. Memberikan beasiswa untuk melanjutkan } \\
\text { universitas di dalam negeri untuk tahapan S2 } \\
\text { m Memberikan beasiswa untuk melanjutkan } \\
\text { universitas keluar negeri untuk tahapan S2 }\end{array}$ \\
\hline
\end{tabular}

Variabel Operasional Kondisi Politik

\begin{tabular}{|c|c|c|}
\hline Variabel & Dimensi & Sub Indikator \\
\hline \multirow{3}{*}{$\begin{array}{l}\text { Kondisi } \\
\text { Politik }\end{array}$} & $\begin{array}{l}\text { Kondisi politik } \\
\text { dinegara } \\
\text { tersebut }\end{array}$ & $\begin{array}{l}\text { a. Kondisi politik dalam keadaan kondusif } \\
\text { b. Tidak terjadi chaos } \\
\text { c. Tidak terjadi demo } \\
\text { d. Hubungan antara eksekutif dengan legislative } \\
\text { dalam keadaan kondusif }\end{array}$ \\
\hline & $\begin{array}{c}\text { Kerangka } \\
\text { hukum }\end{array}$ & $\begin{array}{l}\text { e. Undang-undang yang mendukung dunia } \\
\text { konstruksi } \\
\text { f. Membuat RUU tentang konstruksi } \\
\text { g. Membuat RUU tentang ketenaga kerjaan pada } \\
\text { jasa konstruksi }\end{array}$ \\
\hline & $\begin{array}{l}\text { Hubungan } \\
\text { dengan } \\
\text { pemegang } \\
\text { kekuasaan }\end{array}$ & $\begin{array}{l}\text { h. Adanya perjanjian CAFTA tahun } 2015 \\
\text { i. Menjaga hubungan dengan instansi pemerintah } \\
\text { pusat } \\
\text { j. Menjaga hubungan dengan instansi pemerintah } \\
\text { daerah } \\
\text { k. Menjaga hubungan sekwilda }\end{array}$ \\
\hline
\end{tabular}

\section{Metodologi}

Seperti yang telah dijelaskan sebelumnya pada teknik pengumpulan data, bahwa salah satu teknik pengumpulan data yang digunakan dalam penelitian ini adalah dengan menggunakan kuesioner. Sebelum menyebarkan kuesioner penelitiankepada responden akhir, item-item pernyataan pada kuesioner harus terlebih dahulu di uji 
coba. Uji coba instrument ini dilakukan kepada 30 pegawai PT. Wijaya Karya (Persero) Tbk.

Variabel Operasional Persaingan Usaha

\begin{tabular}{|c|c|c|}
\hline Variabel & Dimensi & Sub Indikator \\
\hline \multirow{5}{*}{$\begin{array}{l}\text { Persaingan } \\
\text { Usaha }\end{array}$} & $\begin{array}{l}\text { Jumlah ukuran } \\
\text { pesaing }\end{array}$ & $\begin{array}{l}\text { a. Jumlah perusahaan konstruksi yang ada di } \\
\text { Indonesia } \\
\text { b. Jumlah organisasi konstruksi di Indonesia } \\
\text { c. Adanya kontraktor asing masuk ke Indonesia } \\
\text { d Kontraktor asing melakukan kerjasama operasi } \\
\text { dengan kontraktor lokal }\end{array}$ \\
\hline & $\begin{array}{l}\text { Frekuensi } \\
\text { perubahan } \\
\text { teknologi } \\
\text { dalam industri }\end{array}$ & $\begin{array}{l}\text { e. Adanya metode kerja yang terbaru } \\
\text { f. Adanya jurnal tentang teknologi konstruksi } \\
\text { g. Adanya tenaga asing yang ekspert }\end{array}$ \\
\hline & $\begin{array}{l}\text { Frekuensi } \\
\text { pengenalan } \\
\text { produk baru }\end{array}$ & $\begin{array}{l}\text { h. Banyaknya vendor dari luar negeri } \\
\text { i. Adanya inovasi produk dari vendor }\end{array}$ \\
\hline & $\begin{array}{l}\text { Tingkat } \\
\text { manipulasi } \\
\text { harga }\end{array}$ & $\begin{array}{ll}\text { j. } & \text { Diskon harga penawaran tender } \\
\text { k. } & \text { Terjadinya KKN pada proses tender } \\
\text { I. Manipulasi data pada proses tender } \\
\text { m. Manipulasi harga pada proses tender }\end{array}$ \\
\hline & $\begin{array}{l}\text { Akses ke } \\
\text { saluran } \\
\text { pemasaran }\end{array}$ & $\begin{array}{l}\text { n. Menjaga hubungan yang baik dengan pemberi } \\
\text { kerja } \\
\text { o. Membuat jaringan kerja dengan pemberi kerja } \\
\text { p. Membuat jaringan kerja dengan vendor } \\
\text { q. Membuat jaringan kerja dengan subkontraktor }\end{array}$ \\
\hline
\end{tabular}


Variabel Operasional Kinerja Perusahaan

\begin{tabular}{|c|c|c|}
\hline Variabel & Dimensi & Sub Indikator \\
\hline \multirow{4}{*}{$\begin{array}{c}\text { Kinerja } \\
\text { Perusahaan }\end{array}$} & Efektifitas & $\begin{array}{l}\text { a. Proses usaha lebih efektif } \\
\text { b. Ketersediaan tenaga kerja sesuai kebutuhan } \\
\text { c. Modal usaha dikelola dengan efektif } \\
\text { d. Program promosi yang efektif } \\
\text { e. Efektifitas pemakaian alat kerja }\end{array}$ \\
\hline & Efisiensi & $\begin{array}{l}\text { f. Proses kerja yang efisien } \\
\text { g. Penilaian kerja yang memperhitungkan } \\
\text { ketepatan waktu } \\
\text { h. Ketepatan waktu kerja dapat membantu } \\
\text { produktifitas karyawan } \\
\text { i. Pemanfaatan waktu kerja sesuai prosedur } \\
\text { j. Pemanfaat sumber daya secara efisien }\end{array}$ \\
\hline & $\begin{array}{l}\text { Peningkatan } \\
\text { penjualan }\end{array}$ & $\begin{array}{l}\text { k. Biaya operasional lebih kecil dari Rencana } \\
\text { Keuangan Anggaran Pelaksanaan } \\
\text { I. Biaya operasional lebih kecil dari biaya } \\
\text { penjualan }\end{array}$ \\
\hline & $\begin{array}{l}\text { Pencapaian } \\
\text { tujuan } \\
\text { perusahaan }\end{array}$ & $\begin{array}{l}\text { m. Pencapaian tujuan jangka pendek } \\
\text { n. Pencapaian tujuan jangka panjang } \\
\text { o. Dilaksanakannya budaya perusahaan dengan } \\
\text { baik } \\
\text { p. Melaksanakan visi perusahaan dengan baik } \\
\text { q. Melaksanakan misi perusahaan dengan baik }\end{array}$ \\
\hline
\end{tabular}

Metode analisis yang juga digunakan dalam penelitian ini adalah regresi berganda (multiple regression). Adapun tujuannya adalah ketika ingin meramalkan bagaimana keadaan (naik turunnya) variabel terikat, bila dua atau lebih variabel bebas sebagai factor predictor dimanipulasi, naik turunkan nilainya.

Persamaan Regresi Berganda

$\mathrm{Y}=\beta_{0}+\beta_{1} X_{1}+\beta_{2} X_{2}+\beta_{3} X_{3}+e$

Keterangan :

$\mathrm{Y}$

$\beta_{0}$

$\beta_{1,} \beta_{2,}, \beta_{3}$

$\mathrm{X}_{1}$

$\mathrm{X}_{2}$

$\mathrm{X}_{3}$
= variabel kinerja perusahaan

$=$ konstanta

$=$ koefisien regresi

= variabel dukungan pemerintah

$=$ variabel kondisi politik

= variabel persaingan usaha

\section{Pembahasan Hasil Penelitian}

Analisis deskriptif memberikan gambaran tentang data yang diperoleh. Gambaran data ini bisa menjadi acuan untuk melihat karakteristik data yang kita 
peroleh. Karakteristik data yang disajikan misalnya nilai rata-rata, minimum, maksimum dan standar deviasi. Berikut adalah gambaran umum berdasarkan data yang diperoleh.

\section{Descriptive Statistics}

\begin{tabular}{|l|l|l|l|l|l|}
\hline & $\mathrm{N}$ & Minimum & Maximum & Mean & Std. Deviation \\
\hline Dukungan Pemerintah (X1) & 133 & 33.00 & 63.00 & 50.8346 & 5.68382 \\
Kondisi Politik (X2) & 133 & 28.00 & 52.00 & 44.1128 & 5.07766 \\
Persaingan Usaha (X3) & 133 & 32.00 & 66.00 & 55.2331 & 5.91081 \\
Kinerja Perusahaan (Y) & 133 & 43.00 & 80.00 & 67.8346 & 7.44289 \\
Valid N (listwise) & 133 & & & & \\
\hline
\end{tabular}

Berdasarkan tabel diatas dapat dilihat nilai rata-rata dari variabel Kinerja Perusahaan (Y) adalah sebesar 67.8346 dengan nilai standard deviasi sebesar 7.44289. Nilai rata-rata dari variabel Dukungan Pemerintah $\left(\mathrm{X}_{1}\right)$ adalah sebesar 50.8346 dengan nilai standard deviasi sebesar 5.68382. Nilai rata-rata dari variabel Kondisi Politik $\left(\mathrm{X}_{2}\right)$ adalah sebesar 44.1128 dengan nilai standard deviasi sebesar 5.07766. Nilai rata-rata dari variabel Persaingan Usaha $\left(\mathrm{X}_{3}\right)$ adalah sebesar 55.2331 dengan nilai standard deviasi sebesar 5.91081.

\section{Hasil Pengujian Persamaan Regresi}

\section{Coefficients $^{\mathbf{a}}$}

\begin{tabular}{|ll|l|l|l|l|l|}
\hline \multirow{2}{*}{ Model } & \multicolumn{2}{|l|}{$\begin{array}{l}\text { Unstandardized } \\
\text { Coefficients }\end{array}$} & $\begin{array}{l}\text { Standardized } \\
\text { Coefficients }\end{array}$ & \multirow{2}{*}{ Sig. } \\
\cline { 2 - 5 } & & $\mathrm{B}$ & Std. Error & Beta & \\
\hline \multirow{4}{*}{1} & (Constant) & 4.705 & 3.051 & & 1.542 & .126 \\
& Dukungan Pemerintah (X1) & .238 & .079 & .182 & 2.996 & .003 \\
& Kondisi Politik (X2) & .722 & .122 & .492 & 5.935 & .000 \\
& Persaingan Usaha (X3) & .348 & .104 & .276 & 3.344 & .001 \\
\hline
\end{tabular}

a. Dependent Variable: Kinerja Perusahaan (Y)

Dari tabel di atas diperoleh persamaan regresi sebagai berikut :

$$
Y=4.705+0.238 X_{1}+0.722 X_{2}+0.348 X_{3}
$$

Dari persamaan regresi linear berganda diatas dapat dijelaskan sebagai berikut: 
1. Koefiensi regresi variabel Dukungan Pemerintah $\left(\mathrm{X}_{1}\right)$ adalah sebesar 0.238, artinya jika variabel independen lain nilainya tetap dan nilai dari Dukungan Pemerintah mengalami kenaikan 1 satuan, maka nilai dari Kinerja Perusahaan akan mengalami kenaikan sebesar 0.238 satuan. Dalam hal ini pengaruh dari variabel independen Dukungan Pemerintah adalah berbanding lurus dengan Kinerja Perusahaan, artinya semakin meningkat Dukungan Pemerintah, maka nilai Kinerja Perusahaan juga akan semakin meningkat, begitu pula sebaliknya.

2. Koefiensi regresi variabel Kondisi Politik $\left(\mathrm{X}_{2}\right)$ adalah sebesar 0.722 , artinya jika variabel independen lain nilainya tetap dan nilai dari Kondisi Politik mengalami kenaikan 1 satuan, maka nilai dari Kinerja Perusahaan akan mengalami kenaikan sebesar 0.722 satuan. Dalam hal ini pengaruh dari variabel independen Kondisi Politik adalah berbanding lurus dengan Kinerja Perusahaan, artinya semakin meningkat Kondisi Politik, maka nilai Kinerja Perusahaan juga akan semakin meningkat, begitu pula sebaliknya.

3. Koefiensi regresi variabel Persaingan Usaha $\left(\mathrm{X}_{3}\right)$ adalah sebesar 0.348, artinya jika variabel independen lain nilainya tetap dan nilai dari Persaingan Usaha mengalami kenaikan 1 satuan, maka nilai dari Kinerja Perusahaan akan mengalami kenaikan sebesar 0.348 satuan. Dalam hal ini pengaruh dari variabel independen Persaingan Usaha adalah berbanding lurus dengan Kinerja Perusahaan, artinya semakin meningkat Persaingan Usaha, maka nilai Kinerja Perusahaan juga akan semakin meningkat, begitu pula sebaliknya.

\section{Hasil Pengujian Uji t}

\section{Coefficients $^{\mathrm{a}}$}

\begin{tabular}{|cl|l|l|l|l|l|}
\hline \multirow{2}{*}{ Model } & \multicolumn{2}{|l|l|}{$\begin{array}{l}\text { Unstandardized } \\
\text { Coefficients }\end{array}$} & $\begin{array}{l}\text { Standardized } \\
\text { Coefficients }\end{array}$ & \multirow{2}{*}{ Sig. } \\
\cline { 2 - 5 } & B & Std. Error & Beta & \\
\hline \multirow{2}{*}{1} & (Constant) & 4.705 & 3.051 & & 1.542 & .126 \\
& Dukungan Pemerintah (X1) & .238 & .079 & .182 & 2.996 & .003 \\
& Kondisi Politik (X2) & .722 & .122 & .492 & 5.935 & .000 \\
& Persaingan Usaha (X3) & .348 & .104 & .276 & 3.344 & .001 \\
\hline
\end{tabular}


a. Dependent Variable: Kinerja Perusahaan (Y)

\section{Hipotesis 1 :}

Terdapat pengaruh antara Dukungan Pemerintah $\left(\mathrm{X}_{1}\right)$ terhadap Kinerja Perusahaan $(\mathrm{Y})($ p-value $0.003<0.05) \rightarrow$ Tolak Ho

Dari tabel diatas menunjukan nilai signifikansi adalah 0.003 yang bernilai lebih kecil dari $\alpha=0.05$, oleh karena itu keputusan adalah Tolak $\mathrm{H}_{0}$. Sehingga dapat disimpulkan bahwa terdapat pengaruh antara Dukungan Pemerintah $\left(\mathrm{X}_{1}\right)$ terhadap Kinerja Perusahaan (Y).

\section{Hipotesis 2 :}

Terdapat pengaruh antara Kondisi Politik $\left(\mathrm{X}_{2}\right)$ terhadap Kinerja Perusahaan (Y). $(p$-value $0.000<0.05) \rightarrow$ Tolak Ho

Dari tabel diatas menunjukan nilai signifikansi adalah 0.000 yang bernilai lebih kecil dari $\alpha=0.05$, oleh karena itu keputusan adalah Tolak $\mathrm{H}_{0}$. Sehingga dapat disimpulkan bahwa terdapat pengaruh antara Kondisi Politik $\left(\mathrm{X}_{2}\right)$ terhadap Kinerja Perusahaan (Y).

\section{Hipotesis 3 :}

Terdapat pengaruh antara Persaingan Usaha $\left(\mathrm{X}_{3}\right)$ terhadap Kinerja Perusahaan (Y). (p-value $0.001<0.05) \rightarrow$ Tolak Ho

Dari tabel diatas menunjukan nilai signifikansi adalah 0.001 yang bernilai kurang dari $\alpha=0.05$, oleh karena itu keputusan adalah Tolak $\mathrm{H}_{0}$. Sehingga dapat disimpulkan bahwa terdapat pengaruh antara Persaingan Usaha $\left(\mathrm{X}_{3}\right)$ terhadap Kinerja Perusahaan (Y). 


\section{Uji F}

\section{Hasil Pengujian Uji F}

ANOVA $^{a}$

\begin{tabular}{|ll|l|l|l|l|l|}
\hline Model & $\begin{array}{l}\text { Sum of } \\
\text { Squares }\end{array}$ & df & $\begin{array}{l}\text { Mean } \\
\text { Square }\end{array}$ & F & Sig. \\
\hline 1 & Regression & 5718.015 & 3 & 1906.005 & 154.217 & $.000^{\mathrm{b}}$ \\
& Residual & 1594.345 & 129 & 12.359 & & \\
& Total & 7312.361 & 132 & & & \\
\hline
\end{tabular}

a. Dependent Variable: Kinerja Perusahaan (Y)

b. Predictors: (Constant), Persaingan Usaha (X3), Dukungan Pemerintah (X1), Kondisi Politik (X2)

\section{Hipotesis 4:}

Terdapat pengaruh antara Dukungan Pemerintah $\left(\mathrm{X}_{1}\right)$, Kondisi Politik $\left(\mathrm{X}_{2}\right)$ dan Persaingan Usaha $\left(\mathrm{X}_{3}\right)$ terhadap Kinerja Perusahaan $(\mathrm{Y})$. (p-value $\left.0.000<0.05\right)$

\section{$\rightarrow$ Tolak Ho}

Dari tabel diatas menunjukan nilai signifikansi adalah 0.000 yang bernilai kurang dari $\alpha=0.05$, oleh karena itu keputusan adalah Tolak $\mathrm{H}_{0}$. Sehingga dapat disimpulkan bahwa terdapat pengaruh antara Dukungan Pemerintah $\left(\mathrm{X}_{1}\right)$, Kondisi Politik $\left(\mathrm{X}_{2}\right)$ dan Persaingan Usaha $\left(\mathrm{X}_{3}\right)$ terhadap Kinerja Perusahaan $(\mathrm{Y})$.

\section{Koefisien Determinasi}

Model Summary ${ }^{\text {b }}$

\begin{tabular}{|l|l|l|l|l|}
\hline Model & R & R Square & Adjusted R Square & Std. Error of the Estimate \\
\hline 1 & $.884^{\mathrm{a}}$ & .782 & .777 & 3.51557 \\
\hline
\end{tabular}

a. Predictors: (Constant), Persaingan Usaha (X3), Dukungan Pemerintah (X1), Kondisi Politik (X2)

b. Dependent Variable: Kinerja Perusahaan (Y)

Dari tabel diatas diperoleh koefisien determinasi atau Adjusted R Square adalah 0.777 artinya 77,7 \% variabel terikat yaitu Kinerja Perusahaan (Y) variasinya dapat dijelaskan oleh variabel Dukungan Pemerintah $\left(\mathrm{X}_{1}\right)$, Kondisi Politik $\left(\mathrm{X}_{2}\right)$ dan Persaingan Usaha $\left(\mathrm{X}_{3}\right)$, sisanya sebesar 22,3 \% dijelaskan oleh variabel diluar variabel yang digunakan. 


\section{Kesimpulan}

Berdasarkan hasil penelitian yang didapatkan, dapat disimpulkan bahwa dukungan pemerintah, kondisi politik dan persaingan usaha secara signifikan berpengaruh positif terhadap kinerja perusahaan.

1. Terdapat pengaruh antara Dukungan Pemerintah $\left(\mathrm{X}_{1}\right)$ terhadap Kinerja Perusahaan (Y) pada perusahaan jasa konstruksi. Pengaruh Koefiensi variabel Dukungan Pemerintah $\left(\mathrm{X}_{1}\right)$ adalah sebesar 0.238, yang artinya jika variabel independen lain nilainya tetap dan nilai dari Dukungan Pemerintah mengalami kenaikan 1 satuan, maka nilai dari Kinerja Perusahaan (Y)akan mengalami kenaikan sebesar 0.238 satuan, begitupula sebaliknya.

2. Terdapat pengaruh antara Kondisi Politik $\left(X_{2}\right)$ terhadap Kinerja Perusahaan (Y) pada perusahaan jasa konstruksi. Pengaruh Koefiensi variabel Kondisi Politik $\left(\mathrm{X}_{2}\right)$ adalah sebesar 0.722 , yang artinya jika variabel independen lain nilainya tetap dan nilai dari Kondisi Politik mengalami kenaikan 1 satuan, maka nilai dari Kinerja Perusahaan (Y)akan mengalami kenaikan sebesar 0.722 satuan, begitupula sebaliknya.

3. Terdapat pengaruh antara Persaingan Usaha $\left(\mathrm{X}_{3}\right)$ terhadap Kinerja Perusahaan (Y) pada perusahaan jasa konstruksi. Pengaruh Koefiensi variabel Persaingan Usaha $\left(\mathrm{X}_{1}\right)$ adalah sebesar 0.348 , yang artinya jika variabel independen lain nilainya tetap dan nilai dari Persaingan Usaha mengalami kenaikan 1 satuan, maka nilai dari Kinerja Perusahaan (Y)akan mengalami kenaikan sebesar 0.348 satuan, begitupula sebaliknya.

4. Terdapat pengaruh secara simultan antara Dukungan Pemerintah $\left(\mathrm{X}_{1}\right)$, Kondisi Politik $\left(\mathrm{X}_{2}\right)$ dan Persaingan Usaha $\left(\mathrm{X}_{3}\right)$ terhadap Kinerja Perusahaan $(\mathrm{Y})$, variabel yang memiliki pengaruh paling signifikan terhadap Kinerja Perusahaan (Y) adalah kondisi politik. Hal ini ditunjukan dari nilai signifikansi yang paling signifikan dibandingkan dengan variabel Dukungan Pemerintah dan Persaingan Usaha. 


\section{Saran}

Dengan telah dibuktikannya pengaruh antara variabel independen terhadap variabel dependen tersebut, maka saran yang dapat diberikan bagi perusahaan jasa konstruksi PT. Wijaya Karya (Persero) Tbk dalam rangka peningkatan Kinerja Perusahaan, antara lain:

1. PT. Wijaya Karya (Persero) Tbk harus melakukan pendekatan dan hubungan yang baik dengan pemberi kerja secara intensif, sehingga kesempatan mendapatkan proyek usaha jasa konstruksi lebih besar.

2. PT. Wijaya Karya (Persero) Tbk bergabung dengan organiasi-organisasi perusahaan seperti GAPENSI, KADIN atau yang lainnya. Ini memungkinkan perusahaan jasa konstruksi lebih banyak mendapat informasi tentang proyekproyek yang akan segera dikerjakan atau di tenderkan.

3. PT. Wijaya Karya (Persero) Tbk melakukan diversifikasi usaha yang tahan terhadap kondisi politik dan melakukan ekspansi usaha jasa konstruksi ke negara lain.

4. Peningkatan kinerja perusahaan, yaitu misalnya dengan berusaha mencapai tingkat pengembalian terhadap penjualan (return on sales) yang telah ditargetkan, memenuhi kebutuhan pelanggan dan mencakup seluruh lingkup pangsa pasar yang ditargetkan.

\section{DAFTAR PUSTAKA}

Adeoye, Abayomi Olarewaju \& Elegunde, Ayobami Folarin (2012). Impacts of External Business Environment on Organisational Performance in the Food and Beverage Industry in Nigeria. British Journal of Arts and Social Sciences ISSN: 2046-9578.

Alfaraih, Mishari., Alanezi, Faisal. dan Almujamed, Hesham., (2012). The Influence of Institutional and Government Ownership on Firm Performance: Evidence from Kuwait. International Business Research Vol. 5, No. 10; 2012 ISSN 1913-9004 E-ISSN 1913-9012. 
Jurnal Riset Manajemen Sains Indonesia (JRMSI) | Vol 7, No. 2, 2016

Alkali, Muhammed.\& Isa, A. H. M., (2012). Assessing the Influence of External Environmental Factors, on the Performance of Small Business Manufacturing enterprises in Bauchi state, Nigeria. Interdisciplinary Journal Of ContemporaryResearch In Business Vol 4, No 7.

Al-Rfou, Ahmad Nahar. (2012). Competition and Organizational Performance: Empirical Evidence from Jordanian Firms. Journal Economics.

Anas, Abrar., Herri dan Karimi, Syafruddin. (2005) Analisa Faktor-Faktor Perusahaan Yang Mempengaruhi Kinerja Ekspor (Studi Kasus Perusahaan Ekspor Di Sumatera Barat). Jurnal Business \& Manajemen Vol. 1, No.1.

Anthony, Robert N. and Vijay Govindarajan, 2004, Management Control System, Eleventh Edition, McGraww Hill.

Ariyanto, Taufik. (2004). Profil Persaingan Usaha Dalam Industri Perbankan Indonesia. Perbanas Finance \& Banking Journal, Vol. 6, No. 2, Desember 2004; 95-108.

Bambang, LS. 2005. Corporate Governance: Isu Utama Penelitian, KOMPAK. No. 2 Juli-Desember p. 163-171.

Barlett, Cristhoper. \& Ghosal, Sumantra, 1994, Changing the Role of Top Management, Harvard BusinessReview $\quad$ (Nopember $\quad-$ Desember). Vol. 30. Iss. 8. 254164.

Basri, N.I.B., 2008. Critical success factors for ibs adoption in Malaysian construction industry. In: Faculty of Civil Engineering. Universiti Teknologi Malaysia, Johor Bharu, Malaysia.

Beal, Reginald. M, 2000, Competing Effectively Environmental Variables on the Entrepreneur Marketing Orientation of Entrepreneur, Entrepreneurship Theory and Practice. Business Research. January.Vol. 15. P. 47-62Cropanzano, Russel, Howes, John C., Grandey, Alicia A., \& Toth, Paul, 1997. The Relationship of rganizational Politic and Support to work Behaviors, Attitudes and Stress, Journal of Organizational Behavior, Vol. 18, p. $159-180$ 
CIDB, 2010. Roadmap for industrialised building system (ibs) in Malaysia 20112015. Construction Industry Development Board (CIDB), Kuala Lumpur, Malaysia.

Colley, John L, Jacouline L Doyle, 2001, Coorporate Sytrategy, New York, MCGraw - Hill.

Daily, Catherine M., dan R. Dalton. 2004. Bankruptcy and Corporate Governance: The Impact of Board Composition and Structure. The Academy of Management Journal. December, Vol. 37(6), 1603-1617

David, Fred, R, 2003, Strategic Management: "Concepts and Cases”, Ninth edition Prentice Hall - USA.

Dwi Putri, N.A. (2011). KEBIJAKAN PEMERINTAH DALAM PENGENDALIAN PENCEMARAN AIR SUNGAI SIAK (Studi pada Daerah Aliran Sungai Siak Bagian Hilir) Jurnal Ilmu Politik dan Ilmu Pemerintahan, Vol. 1, No. 1.

Endraswari, Rizki Mariskha. (2006). Faktor-faktor yang Mempengaruhi Aplikasi TI dan Pengaruhnya Terhadap Kinerja Perusahaan, Studi pada UKM Kerajinan Tangan di Bantul, Yogyakarta. Tesis Universitas Diponegoro.

FCGI. 2001, Corporate Governance; Tata Kelola Perusahaan. Jakarta

Gendut Suprayitno, dkk. 2008. Good Corporate Governance sebagai Budaya. Jakarta: The Indonesian Institute for Corporate Governance.

Ghozali, H. Imam. 2012. Aplikasi Analisis Multivariate dengan Program IBM SPSS. Edisi Keenam. Semarang: Universitas Diponegoro.

J. David Hunger, Thomas. L. Wheelen, 2007, Strategic Management an Business Policy, Prantice Hall Upper Saddle River, New Jersey

Koetin, Erwin. E. 1994, Suatu Pedoman Investasi dalam Efek di Indonesia, Bursa Efek Jakarta

Kusmayadi, Dedi., (2008).Pengaruh Lingkungan Bisnis Terhadap Kinerja Perusahaan: Sebuah Tinjauan Teoritis dan Empiris. Jurnal Akuntansi FE Unsil, Vol. 3, No. 2, 2008 ISSN: 1907 - 9958. 
Lazim, Yusra Yaseen dan Azlinna Binti Azizan, Noor (2013). The influence of human resources management practices, and government's role in the organizational performance of small businesses in Malaysia. Asian Journal of Management Research Volume 4 Issue 2

Lestari, Fitra D.,\& Suzanti, Lizza., (2011).Pengaruh Perilaku Kewirausahaan dan Persaingan Terhadap Pendapatan Usaha Pedagang di daerah Wisata Pantai Pangandara. Portal Jurnal Universitas Pendidikan Indonesia, Jurnal 6, Nomor 1.

Mashhadi, Aazir Hammad. dan Ijaz-Ur-Rehman, Qazi. (2012). Impact of External Environment on the Performance of the Fast Food Industry. International Journal of Management, Economics and Social Sciences

Meiliawati. (2012). Pengaruh Dinamika Lingkungan Bisnis Terhadap Pengambilan Keputusan Terkait Sistem Pengendalian Manajemen Yang Ada di UD Mega Jaya. Jurnal Ilmiah Mahasiswa Universitas Surabaya Vol. 1 No. 1.

Muh. Arief Effendi. 2009. The Power of Good Corporate Governance: Teori dan Implementasi. Jakarta: Salemba Empat.

Nova, Firsan. (2014)The influence of market attractiveness and core competence on value creation and competitive advantage and its implication on business Performance (A study at Pay TV Industry in Indonesia). Jurnal International Journal of Education and Research Vol. 2 No. 8.

Porter, M. E. (1990). The Competitive Advantage of Nation. First Edition, New York: Free Press.

Porter, E. M. 1986, Competitive Advantage: Creating and Sustaining SuperiorPerformance, Published by Simon and Schuster Newyork.

Pudjadi, Tri., Kristianto dan Tommy, Andre. (2007). Analisa Untuk Perencanaan Strategi Sistem dan Teknologi Informasi Pad PT. Ritrans Cargo. Seminar Nasional Aplikasi Teknologi Informasi 2007 (SNATI 2007) ISSN: 19075022 . 
Ranawat, Mahipat. dan Tiwari, Rajnish. (2009). Influence of Government Policies on Industry Development: The Case of India's Automotive IndustryWORKING PAPER Technology and Innovation Management.

Statistik, Badan Pusat., (2012). Pertumbuhan Ekonomi Indonesia. No. 14/02/Th. XVI, 5 Februari 2013. Hal 2-5.

Setyawan, Komang M.,\& Putri, I G. A. M. A. D.,(2013).PengaruhGood Corporate Governance Terhadap Kinerja Keuangan Lembaga Perkreditan Desadi Kecamatan Mengwi Kabupaten Badung.E-Jurnal Akuntansi Universitas Udayana 5.3 (2013):586-598. ISSN: 2302-8556.

Taherkhani, R., Saleh, A. L., Nekooie, Mohammad Ali, dan Mansur, Shaiful Amri (2012). External Factors Influencing on Industrial Building System (IBS) in Malaysia. International Journal of Sustainable Development \& World Policy 1(2) :66-79 (2012)

Torjman (2005): “What is policy?”, Caledon Institute of Social Policy, Canada, online in internet: Format: www.caledoninst.org/Publications/PDF/544ENG.pdf, Enquiry: [22.09.08]; Time: [13:06].

Wati, Like M.,(2012). Pengaruh Praktek Good Corporate Governance Terhadap kinerja keuangan Perusahaan di Bursa Efek Indonesia.Jurnal Manajemen, Volume 01, Nomor 01.

Zajac, E. J., Matthew S Kraatz, Rudi K.P. Bresser, 2000, Modeling Dynamics of Strategic Fit : A Normative Approach to Strategic Change, Strategic Management Journal, Apr.Vol 21, N0. 4. P. 213-226. 